\title{
DNA probes, targeting large sub-unit rRNA, for the rapid identification of the paralytic shellfish poison producing dinoflagellate, Gymnodinium catenatum
}

\author{
LESLEY RHODES \\ KIRSTY SMITH \\ Cawthron Institute \\ Private Bag 2 \\ Nelson, New Zealand \\ MIGUEL DE SALAS \\ Department of Plant Sciences \\ University of Tasmania \\ GPO Box 252-55 \\ Hobart, Australia
}

\begin{abstract}
The dinoflagellate Gymnodinium catenatum was first observed in New Zealand at Manukau Harbour on the west coast of the North Island in May 2000. At that time, a strong correlation was evident between the micro-algal bloom and the occurrence of paralytic shellfish toxins (PSP) in shellfish. This paper describes the design and testing of oligonucletide probes targeting the large sub-unit (LSU) ribosomal RNA (rRNA) of G. catenatum. The probes were developed in fluorescent in situ hybridisation (FISH) and sandwich hybridisation assay (SHA) format to rapidly differentiate the target PSP producer from non-toxic look-alike dinoflagellates. Specificity was affirmed by testing the probes against dinoflagellate and flagellate isolates.
\end{abstract}

Keywords fluorescent in situ hybridisation (FISH); sandwich hybridisation assay (SHA); harmful algal blooms; oligonucleotide probes

M07032; Online publication date 27 November 2007; Received 27 June; accepted 12 September 2007

\section{INTRODUCTION}

Gymnodinium catenatum Graham (Dinophyceae) was first detected along the northwest coastline of New Zealand following the detection of paralytic shellfish poisons (PSP) in shellfish in May 2000. During that bloom event, PSP toxicity reached $4027 \mu$ g saxitoxin equivalents/100 $\mathrm{g}$ in Greenshell ${ }^{\mathrm{TM}}$ mussels (Perna canaliculus; Mackenzie \& Beauchamp 2001). There were concerns that $G$. catenatum cysts, which were detected with mussel spat on seaweed collected from Ninety Mile Beach, could be transferred to marine farms when the spat-bearing seaweed was transported to the commercial mussel growing areas (Taylor \& Mackenzie 2001). Gymnodinium catenatum has increased its geographic range around the entire North Island coastline of New Zealand over the last 6 years, and annual blooms are likely in some areas (New Zealand Food Safety Authority unpubl. data). Routine phytoplankton monitoring of sea water is carried out weekly at approximately 100 sites around New Zealand to inform shellfish harvesters of the potential for toxins in shellfish (Rhodes et al. 2001). Analyses are currently carried out at the Cawthron Institute, with results expected within $24 \mathrm{~h}$. This monitoring data is critical for shellfish harvesting management decisions in New Zealand.

Efforts to differentiate $G$. catenatum from the look-alike, non-toxic G. impudicum (Fraga et Bravo) G. Hansen and Moestrup (Fig. 1) using light microscopy (LM) can be difficult, particularly at the onset of blooms when only a few individual cells per litre are present in seawater samples. The morphology of $G$. catenatum cells can also be variable (Fig. 1) adding to the difficulties of LM identification and slowing phytoplankton analyses. To allow differentiation between the target paralytic shellfish toxin (PSP) producer G. catenatum and, in particular, G. impudicum, the present study was aimed at developing DNA probes that target the large sub-unit (LSU) ribosomal RNA (rRNA) of G. catenatum. The specificity of the fluorescent in situ hybridisation (FISH) assay ensures a rapid and definitive answer with a limit of detection (LoD) 


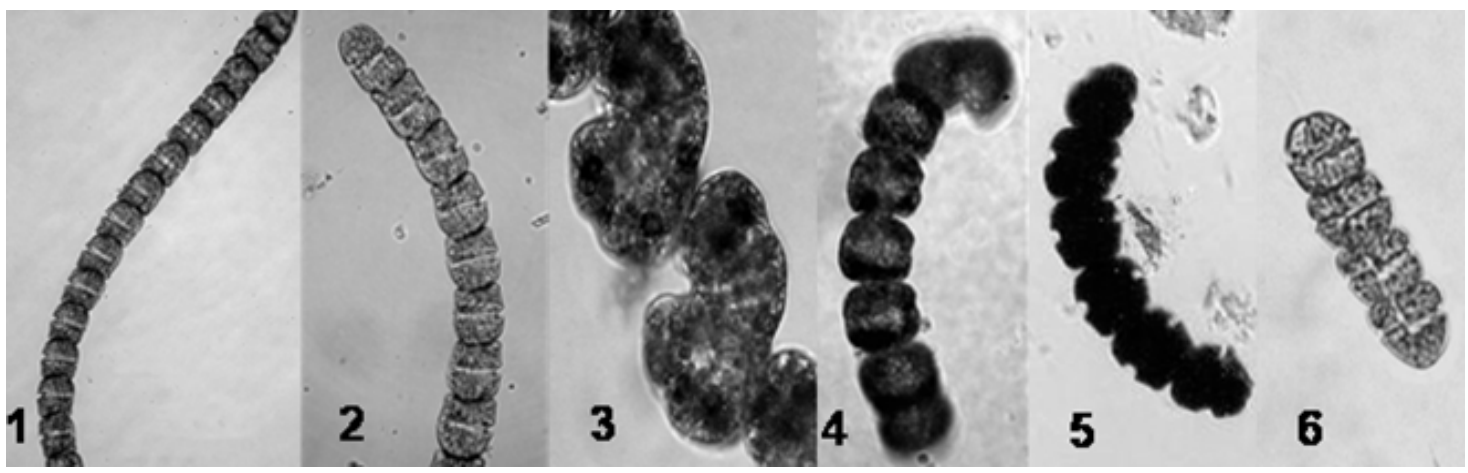

Fig. 1 Light micrographs of Lugol's iodine solution treated Gymnodinium catenatum (1-5) and G. impudicum (6) observed in seawater samples collected during weekly phytoplankton monitoring.

Table 1 Probe designs tested for the detection of Gymnodinium catenatum in fluorescent in situ hybridisation (FISH) and sandwich hybridisation assay (SHA) format. Probes which elicited a positive result for G. catenatum, and which were negative for species tested for cross-reactivity, are in bold.

\begin{tabular}{ll}
\hline Probe designation & Probe designs \\
\hline FISH & CAG CGC GTC GAG AGA TTA C \\
GC84 & CCC TCA GTG ATT CGC TTT TC \\
GC174 & TGG AAT AGA AGG TGA TCA TTG C \\
Gcat403 & CCC ACA AAG GTT GAA CTG TT \\
Gcat575 & \\
SHA capture probe & GTG ATC ATT GCT GCG TGC GAC A \\
Gcat410 & CCC ACC GCC CCG CTT TCG CTG \\
Gcat442 & GGT TGA ACT GTT TGT TGG TGG GTC CCG C \\
Gcat578 & \\
SHA signal probe & CTC ATC CCT GTT CAT TCG CCA TTA C \\
Gcat40 & TTC CAT CCG CTT TCC TTT CAG \\
Gcat368 & GTC TTT CGC CCC TAT ACC CAA GTA TG \\
Gcat 1005 & \\
\hline
\end{tabular}

a, Species-specific response, but weaker than selected probe.

b, SHA signal probes Gcat40 and Gcat368 are to be used in combination.

for both LM and FISH monitoring of 100 cells litre $^{-1}$, based on Cawthron Institute micro-algae laboratory protocols (which meet NZS/ISO/IEC 17025 standards).

In this study oligonucleotide probes, designed in both FISH and sandwich hybridisation assay (SHA) format, were tested against cultured $G$. catenatum strains and related dinoflagellate species.

\section{MATERIALS AND METHODS}

Cultures used for testing probes for specificity of algae collected from the northwest coast of North Island, New Zealand and from Tasmania, Australia, were held in the Cawthron Institute Culture Collection of Micro-algae (CICCM; New
Zealand) and the University of Tasmania Collection of Micro-algae, respectively. CICCM cultures were maintained in GP medium (Loeblich \& Smith 1968), GP50\% modified medium (GP, but with $50 \%$ of the reagent concentrations and full strength sea water), or L1 medium (Guillard \& Hargraves 1993), under standard growth conditions of $100 \mu \mathrm{Ein} \mathrm{m}^{-2} \mathrm{~s}^{-1}$ photon flux (14h:10h light:dark) and $18^{\circ} \mathrm{C}\left( \pm 1^{\circ} \mathrm{C}\right)$. University of Tasmania cultures were maintained in GSe medium (Blackburn et al. 2001).

Regions of unique LSU rRNA G. catenatum sequences were identified in an alignment containing representatives of all major dinoflagellate groups. Several different potential probes (supplied by Oligos Etc Inc., United States) were designed in FISH and SHA format (Table 1) and tested for crossreactivity against a number of dinoflagellate species 
(Table 2). FISH and SHA assays were carried out as described previously (Scholin et al. 1996, 1997, 2003; Miller \& Scholin 1996).

For the FISH assay, the positive control probe, UNIC (a universally conserved sequence), and negative control probe, UNIR (the complement of UNIC), were used for each assay and the filters carrying fluorescent-tagged DNA probed cells were observed under an Olympus epifluorescent microscope (excitation $490 \mathrm{~nm}$; emission $520 \mathrm{~nm}$ ). Cells of fragile species, e.g., Karenia spp., may lyse during the first filtration step of the FISH assay. To avoid lysis, sample fixative $(5 \mathrm{ml}$; Miller \& Scholin 2000) was added to the $10 \mathrm{ml}$ culture before filtration, and cultures were subsequently concentrated by filtration (to $2 \mathrm{ml}$ ), before more fixative was added $(5 \mathrm{ml})$. Filters were not run dry.
Three SHA capture probes and three signal probes were tested in all combinations (Table 1). The capture probe selected for further testing was 5'-Biotin-(C9)3-5'GTGATCATTGCTGCGTGCG ACA. Two signal probes were selected: $5^{\prime}$-Dig- $-5^{\prime} \mathrm{C}$ TCATCCCTGTTCATTCGCCATTAC and 5'-Dig5'5'TTCCATCCGCTTTCCTTTCAG (to be used in combination). Reagents were prepared and the SHA assay was carried out as described previously (Scholin et al. 1996; Goffredi et al. 2006). Precoated, quality control tested prong strips and assay reagents (ORCA Research, Seattle, Washington) were used; probes were gel purified for FISH and SHA (Oligos Etc Inc., United States). The signal probes were used in duplicate as a cocktail and each of the working signal probe stocks $(100 \mathrm{ng} / \mu \mathrm{l})$ were added to $0.5 M$ signal base buffer $(15 \mathrm{ml}$ centrifuge

Table 2 Cross-reactivity testing against dinoflagellates to determine specificity of the Gymnodinium catenatum fluorescent in situ hybridisation (F) and sandwich hybridisation assay (S) probes. (CAW, Cawthron Institute Culture Collection of Micro-algae; UTas, Collection of Micro-algae, University of Tasmania. N, negative; +++ , strong positive.)

\begin{tabular}{|c|c|c|}
\hline Species & Culture collection code & Probe response \\
\hline Akashiwo sanguinea $^{\mathrm{FS}}$ & CAWD01 & $\mathrm{N}$ \\
\hline Amphidinium operculatum ${ }^{\mathrm{FS}}$ & CAWD42,56 & $\mathrm{N}$ \\
\hline Chattonella antiqua $\mathrm{s}$ & CAWR18 & $\mathrm{N}$ \\
\hline C. verruculosa ${ }^{\mathrm{S}}$ & CAWR21 & $\mathrm{N}$ \\
\hline Coolia monotis & CAWD77 & $\mathrm{N}$ \\
\hline Fibrocapsa japonicas & CAWR02 & $\mathrm{N}$ \\
\hline Gymnodinium aureolum $^{\mathrm{FS}}$ & CAWD59 & $\mathrm{N}$ \\
\hline $\begin{array}{l}\text { G. } \text { catenatum }^{\mathrm{FS}} \\
\text { “. }\end{array}$ & CAWD101,102,105,108,109; & +++ \\
\hline G. falcatum ${ }^{\mathrm{S}}$ & UTas GFPL01 & N \\
\hline G. geminatum $\mathrm{s}$ & UTas GGTRA01 & $\mathrm{N}$ \\
\hline G. impudicum $\mathrm{FS}$ & CAWD03,139,140 & $\mathrm{N}$ \\
\hline G. instriatum ${ }^{\mathrm{FS}}$ & CAWD137 & $\mathrm{N}$ \\
\hline G. simplex $\mathrm{FS}^{\mathrm{S}}$ & CAWD86 & $\mathrm{N}$ \\
\hline G. uncatenum ${ }^{\mathrm{S}}$ & UTas GUNWB01 & $\mathrm{N}$ \\
\hline Karenia $_{\text {bidigitata }} \mathrm{FS}$ & CAWD92 & $\mathrm{N}$ \\
\hline K. brevis $^{\mathrm{FS}}$ & CAWD04,122 & $\mathrm{N}$ \\
\hline K. brevisulcata ${ }^{\mathrm{FS}}$ & CAWD82 & $\mathrm{N}$ \\
\hline K. mikimotoi ${ }^{\mathrm{FS}}$ & CAWD63 & $\mathrm{N}$ \\
\hline K. papilionacea ${ }^{\mathrm{FS}}$ & CAWD91 & $\mathrm{N}$ \\
\hline K. selliformis $\mathrm{FS}^{\mathrm{S}}$ & CAWD79 & $\mathrm{N}$ \\
\hline K. umbella ${ }^{\mathrm{FS}}$ & CAWD65,131 & $\mathrm{N}$ \\
\hline Karlodinium veneficum ${ }^{\mathrm{FS}}$ & CAWD83,84 & $\mathrm{N}$ \\
\hline Kryptoperidium foliaceum $\mathrm{S}$ & UTas KFCR01 & $\mathrm{N}$ \\
\hline $\begin{array}{l}\text { Lepidodinium chlorophorum } \\
(=\text { Gym. chlorophorum })^{\mathrm{S}}\end{array}$ & CAWD62 & $\mathrm{N}$ \\
\hline Prorocentrum compressum ${ }^{\mathrm{FS}}$ & CAWD31 & $\mathrm{N}$ \\
\hline Takayama helix ${ }^{\mathrm{FS}}$ & CAWD128 & $\mathrm{N}$ \\
\hline T. tasmanica ${ }^{\mathrm{FS}}$ & CAWD114 & $\mathrm{N}$ \\
\hline Togula jolla $\mathrm{S}$ & CAWD41 & $\mathrm{N}$ \\
\hline
\end{tabular}


tube, Falcon) to a final concentration of $150 \mathrm{ng} / \mathrm{ml}$ for each signal probe in the cocktail. Plate loading (96-well flat-bottomed plates, Becton, Dickinson and Co., United States) was at $250 \mu 1$ volume per well and aliquoted in the following order: wash buffer-E to rows $\mathrm{B}, \mathrm{C}$, and $\mathrm{E}$; signal probe working solution to row F; capture probe working solution to row $\mathrm{G}$; $\alpha$ Dig-HRP Conjugate (1X) in row D and substrate to row A. The lysed sample was obtained by filtration and hybridisation at $85^{\circ} \mathrm{C}$ for $5 \mathrm{~min}$, followed by filtration (Ayers et al. 2005), and was added to row $\mathrm{H}$. The automated processor was run at $28^{\circ} \mathrm{C}$.

Seawater samples were spiked with cultured cells and analysed and a standard curve derived from a scatter plot for G. catenatum based on SHA optical density estimates versus light microscopy counts $(n=42)$. The results were based on light microscopic counts of cells in both exponential and stationary phase to allow a realistic estimate of cell numbers in any given field sample. An optical density reading of $<0.1$ was considered negative. From the standard curve, a graph was generated to be used as a tool for estimating cell numbers during a bloom event after removal of outliers and application of linear regression.

\section{RESULTS AND DISCUSSION}

Several probe designs in FISH and SHA format were tested for specificity to G. catenatum (Table 1). The rRNA molecule secondary structure was not considered when deciding where to place the oligonucleotides, though the probe locations tended to fall within the loop regions of the variable domains D1 and D2 of the rRNA molecule. As these regions do not have a complementary strand, as helices do, they are less constrained in their mutation potential and are the regions where variation among close relatives is most likely. However, this is not always the case and, when designing the $G$. catenatum probes, we considered it more of a curiosity than a design consideration, as the probes were always tested empirically.

The most suitable FISH probe was selected following cross-reactivity testing of closely related dinoflagellates (Table 2) and the hybridisation step of the assay was optimal at $1 \mathrm{~h}$ and $50^{\circ} \mathrm{C}$ (wash buffer room temperature). The FISH probe selected was 5'fluorescein- 5'CAGCGCGTCGAGAGATTAC. The probe was specific for the 7 strains of G. catenatum (Fig. 2) tested and gave a negative response for 17 other dinoflagellates, including G. impudicum and 5

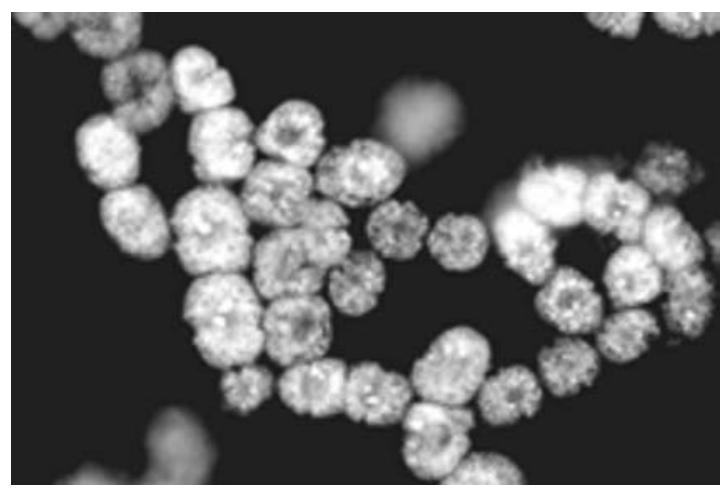

Fig. 2 Light micrographs of Gymnodinium catenatum cells assayed (fluorescent in situ hybridisation) with an oligonucleotide probe targeted at rRNA. Bar $=30 \mu \mathrm{m}$.

other species in the Gymnodiniaceae, and 10 species in the Kareniaceae (Table 2).

The LoD for the FISH probe is 100 cells litre ${ }^{-1}$ based on laboratory protocols which meet NZS/ ISO/IEC 17025 standards and which stipulate $10 \mathrm{ml}$ of sample, but this LoD can be improved by using greater sample volumes.

SHA probes were tested for specificity against isolates of G. catenatum from Manukau Harbour, Manganui Bluff and Ninety Mile Beach (northeastern New Zealand), and two isolates from Georges Bay, Tasmania. All resulted in a positive assay response. The probes were tested for cross-reactivity against 24 dinoflagellates and 3 raphidophytes, including 8 species in the Gymnodiniaceae and 10 in the Kareniaceae. All were negative, as none resulted in a colour reaction (Table 2). Results were based on a standard curve developed using cultured $G$. catenatum cells (Fig. 3). Phytoplankton monitoring laboratories, or shellfish harvesters planning to use this rapid assay $(1 \mathrm{~h})$ on site, should develop a specific standard curve based on a bloom event in their region.

The LoD for the SHA, based on a cultured strain of G. catenatum, was c. 300 cells per well. Therefore, for example, the sample size for sea water containing 12000 cells litre ${ }^{-1}$ would need to be $100 \mathrm{ml}$ to ensure cells were detected (sample to be filtered and resuspended in $1 \mathrm{ml}$ lysis buffer). This LoD means that although the SHA provides a rapid tool for following the spread of blooms, it will be constrained in the detection of the early onset of blooms by the available sample volume. If only small sample volumes are available, PCR-based assays may prove useful for detection of very low cell concentrations, 


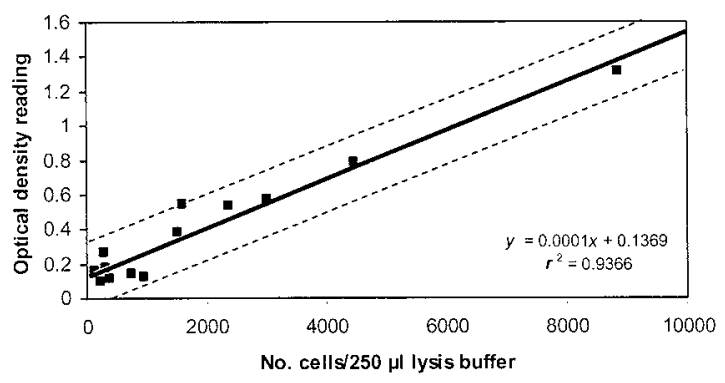

Fig. 3 Standard curve for estimating Gymnodinium catenatum cell numbers from sandwich hybridisation assay results, based on optical density readings.

as has been demonstrated for ballast water testing and environmental samples in Tasmanian waters, Australia (Patil et al. 2005).

For cross-reactivity testing, no cultures of $G$. nolleri Ellegaard et Moestrup or G. microreticulatum Bolch \& Hallegraeff were available; these species have not as yet been identified in New Zealand waters. However, as these species are not chain formers, and G. microreticulatum is a smaller cell than its look-alike congeners, LM differentiation should not be as problematic as for G. impudicum (Bolch \& Reynolds 2002).

The availability of DNA probes for G. catenatum will speed up species identification, with the option for on-site monitoring. The shellfish industry can have confidence that a reported positive for $G$. catenatum is a positive for the toxic species and not its non-toxic look-alikes. Recreational shellfish gatherers will also be protected through the use of the probes by public health officials.

\section{ACKNOWLEDGMENTS}

Thanks to Melissa Marfell and Janet Adamson for excellent technical help. The study was supported by the New Zealand Foundation for Research, Science and Technology, Contract CAWX0301.

\section{REFERENCES}

Ayers K, Rhodes LL, Gladstone M, Scholin C 2005. International accreditation of sandwich hybridisation assay format DNA probes for micro-algae. New Zealand Journal of Marine and Freshwater Research 39: 1225-1231.
Blackburn SI, Bolch CJS, Haskard KA, Hallegraeff GM 2001. Reproductive compatibility among four global populations of the toxic dinoflagellate Gymnodinium catenatum (Dinophyceae). Phycologia 40: 78-87.

Bolch JS, Reynolds MJ 2002. Species resolution and global distribution of microreticulate dinoflagellate cysts. Journal of Plankton Research 24: 565-578.

Goffredi SK, Jones WJ, Scholin CA, Marin R, Vrijenhoek RC 2006. Molecular detection of marine invertebrate larvae. Marine Biotechnology 8: 1-12.

Guillard RRL, Hargraves PE 1993. Stichochrysis immobilis is a diatom, not a chrysophyte. Phycologia 32: 234-236.

Loeblich AR, Smith VE 1968. Chloroplast pigments of the marine dinoflagellate Gyrodinium resplendens. Lipids 3: 5-13.

MacKenzie L, Beauchamp T 2001. Gymnodinium catentum in New Zealand: a new problem for public health and the shellfish industry. Cawthron Institute, Report No. 633. 10 p.

Miller PE, Scholin CA 1996. Identification of cultured Pseudo-nitzschia (Bacillariophyceae) using species-specific LSU rRNA-targeted fluorescent probes. Journal of Phycology 32: 646-655.

Miller PE, Scholin CA 2000. On detection of Pseudonitzschia species using rRNA-targeted probes: sample fixation and stability. Journal of Phycology 36: $238-250$.

Patil JG, Gunasekera RM, Deagle BE, Bax NJ, Blackburn SI 2005. Development and evaluation of a PCR based assay for detection of the toxic dinoflagellate, Gymnodinium catenatum (Graham) in ballast water and environmental samples. Biological Invasions 7: 983-994.

Rhodes L, Scholin C, Garthwaite I 2001. Harmful algae and mariculture in New Zealand. ICES Journal of Marine Science 58: 398-403.

Scholin CA, Buck KR, Britschgi T, Cangelosi G, Chavez F 1996. Identification of Pseudo-nitzschia australis (Bacillariophyceae) using rRNA-targeted probes in whole cell and sandwich hybridisation formats. Phycologia 35: 190-197.

Scholin CA, Miller P, Buck KR, Chavez F, Harris P, Haydock P, Howard J, Harris P, Cangelosi G 1997. Detection and quantification of Pseudo-nitzschia australis in cultured and natural populations using LSU rRNA-targeted probes. Limnololgy and Oceanography 42: 1265-1272. 
Scholin C, Vreiling E, Peperzak L, Rhodes L, Rublee P 2003. Detection of HAB species using lectin, antibody and DNA probes. In: Hallegraeff GM, Anderson DM, Cembella AD ed. Manual on harmful marine micro-algae. UNESCO Publishing. Pp. 131-164.

Taylor, MD, Mackenzie LA 2001. Delimitation survey of the toxic dinoflagellate Gymnodinium catenatum in New Zealand. Report for New Zealand Ministry of Fisheries. Cawthron Institute, Report No. 661. $32 \mathrm{p}$. 
Copyright of New Zealand Journal of Marine \& Freshwater Research is the property of Royal Society of New Zealand and its content may not be copied or emailed to multiple sites or posted to a listserv without the copyright holder's express written permission. However, users may print. download, or email articles for individual use. 